Egyptian Journal of Aquatic Biology \& Fisheries

Zoology Department, Faculty of Science,

Ain Shams University, Cairo, Egypt.

ISSN $1110-6131$

Vol. 24(4): 479 - 495 (2020)

www.ejabf.journals.ekb.eg

\title{
Impacts of natural and experimental phenol pollution on the reproductive performance, vitellogenin synthesis and pathological alterations of male Oreochromis niloticus
}

\section{Ghada Soliman $^{1}$, Mohamed Abdelaziz ${ }^{2}$, Alaa Eldin Eissa ${ }^{2 *}$, Nashwa Elias ${ }^{1}$ Mohamed Moustafa ${ }^{2}$}

${ }^{1}$ Fish Diseases Department, Animal Health Research Institute, Dokki, Giza, Egypt

${ }^{2}$ Department of Aquatic Animal Medicine and Management, Faculty of Veterinary Medicine, Cairo University, Giza 11221 Egypt

"Corresponding Author: aeissa2005@gmail.com

\section{ARTICLE INFO}

Article History:

Received: June 15, 2020

Accepted: July 6, 2020

Online: July 9, 2020

Keywords:

Nile tilapia,

Oreochromis niloticus,

Phenol,

Pollution,

Reproduction,

Performance.
ABSTRACT

Phenol is one of the most toxic chemicals on the health status of fish, which produces several endocrine-disrupting effects on fish. This study comprised two parts: one was the field investigation of phenol pollution on male (Oreochromis niloticus) collected from River Nile branch at the vicinity of Coke Factory at Tebin locality (Helwan) and the other was the experimental investigation of phenol on male Oreochromis niloticus collected from a private farm to monitor the effect of phenol pollution on fish reproduction and health status. The levels of natural phenol residues were $1.4 \mathrm{ppm}$ in the liver of fish and $0.02 \mathrm{ppm}$ in the water site of collection. A total of 80 male Oreochromis niloticus were exposed to 30 $\mathrm{mg} / \mathrm{l}$ phenol for periods of 21, 28, 35, and 45 days while another 20 fish were kept as control. Results found a significant decrease in growth measurements; gonado-somatic index; relative fecundity; sperm density; sperm live \%; aspartate aminotransferase (AST). In contrast, total protein; albumin; alanine aminotransferase (ALT); glucose, and estradiol (E2)-were showed a significant increase. Histopathological examination of hepatocytes showed a remarkable degree of necrosis. A significant number of testicular tubules showed complete loss of spermatogenic contents. Electrophoretic analysis of serum for vitellogenin revealed the appearance of two bands in protein marker. The first band appeared after 21, 28, and 35 days, while the second band appeared after 45 days. Ultimately, laboratory investigations concluded that phenol possesses an estrogenic endocrine disrupting effect.

\section{INTRODUCTION}

Nile tilapia (Oreochromis niloticus) is the most important cultured Cichlid species across the Egyptian state and the predominant fish species in river Nile. The Egyptian aquatic system receives enormous amounts of environmental pollutants through dumping off industrial, agricultural and municipal wastes. The biggest majority of these wastes originate from the agriculture (pesticides, herbicides and insecticides) or industrial effluents (Barakat, 2004; Eissa et al., 2009). Environmental contamination of water 
threatens the continuity and survival of fish. Phenol and synthetic resins are considered the most deleterious types of environmental pollutants with direct jeopardy to the entire aquatic system which found in higher concentrations in fish and represented as being cyanogenic by United States Environmental Protection Agency (USEPA) (Hori et al., 2006; Abdel-Hameid, 2007; Das et al., 2013; Eissa etal. 2013), they were the main organic constituents found in effluents of coal conversion processes or coke ovens (Michalowicz and Duda, 2007; El-Ashtoukhy et al., 2013). The Egyptian national standards have a proportionally zero tolerance to phenol and phenolic compounds $(0.005$ ppm) as detailed in Subject 66/ Egyptian national decree 8/1983. In water, the world Health Organization WHO (1993a, 2002b, 2003c) prescribed $0.001 \mathrm{mg} / \mathrm{L}$ as the permissible concentration of phenol. FAO, (1983) declared that the permissible level of synthetic phenolic resins compounds in fish is $0.01 \mathrm{ppm}$. The Endocrine Disrupting Chemicals (EDCs) are considered as environmental pollutant combined with serious international concern (Bin- Dohaiash, 2010) and exhibit estrogenic effects. Many of these compounds are industrial contaminants, such as pesticides and plasticizers (Mclachlan et al.,2006). In fish, endocrine disruption of the reproductive system has been observed worldwide in numerous species and is known to affect both males and females. Both natural and synthetic endocrine disrupting chemicals (EDCs) are able to cause many disorders and interferences with animal endogenous hormones systems (Zaccaroni et al., 2009). It has been reported that phenol and m-cresol can act as endocrine disruptors and as such impair steroidogenesis (Remya et al., 2014). An endocrine disruptor interrupt normal development and cause male fish to have female characteristics (feminization) accompanied by reduced fertility and even sterility in adults, as well as lowering hatching rates and viability of offspring (Khan and Law, 2005; Sun et al., 2020). Kime et al. ، (1999) defined vitellogenin (VTG) as a good biomarker for understanding the EDCs contaminations in wild animals. VTG is precursor protein of yolk in oviparous animals and is usually produced under endogenous estrogen stimulation in the liver of females. On the other hand, immature females and all males although carry VTG gene still have no or low concentrations of VTG in the blood. However, VTG is induced by exposure to exogenous estrogenic chemicals in immature females and males. In male fish, VTG concentrations are usually undetectable or low, but can be induced upon exposure to estrogenic chemicals as endocrine disruptors either via water or through diet. Estrogenic xenobiotics (xenoestrogens) as alkylphenol, bisphenol, and octylphenol can also act on the estrogen receptors (ER) on hepatocytes to induce the synthesis of vitellogenin which used as biochemical marker for feminization in fish (Park et al., 2003; Tollefsen et al., 2008). This study was designed to examine phenol effect on Oreochromis niloticus growth parameters, relative fecundity, reproductive performance, biochemical parameters and pathological changes influenced experimentally exposed to $1 / 10$ LC50 phenol after $21,28,35$ and 45 days.

\section{MATERIALS AND METHODS}

A total of 50 male $O$. niloticus with average weight $70 \mathrm{~g}$ together with water samples were collected from River Nile branch at El-Tebin (Helwan) locality where ELNasser factory for coke and chemicals located between longitude 31 $19^{\prime} 03.2^{\prime \prime} \mathrm{E}$ and $29^{\circ} 46^{\prime} 03.4^{\prime \prime} \mathrm{N}$ latitude. Sex determination was occurred manually through the shape of genital pore. Phenol investigation from the collected water samples using 
spectrophotometer according to Goulden et al. (1973), and from fish liver using spectrophotometer according to Deichmann and Scott (1939).

A total of 130 apparently healthy adult male Oreochromis niloticus with an average body weight $100 \pm 20 \mathrm{~g}$ were collected from a private fish farm at Port Said Governorate during mid-summer season. Fish were transferred to Fish Diseases Department Laboratory at Animal Health Research Institute (AHRI) then distributed in well aerated glass aquaria where temperature was adjusted at $27 \pm 2{ }^{\circ} \mathrm{C}$. Fish were acclimated prior to experiment. They were fed a balanced commercial fish diet with protein content $30 \%$ throughout the study to avoid the effects of starvation on normal physiological processes.

\section{Experimental design}

In this study, we used technical grade of phenol $(\mathrm{C} 6 \mathrm{H} 5 \mathrm{OH})$ that was obtained from ElGomhorria Pharmaceutical Chemical Company, Cairo, Egypt. About 30 apparently healthy male $O$. niloticus were subjected to five phenol concentrations (20,25, 30, 35 and 40) ppm, and observed for $96 \mathrm{hrs}$. The LC50 was calculated according to Litchfield and Wilcoxon (1949) by using following equation: LC50 = Largest dose $-\sum$ A x B / N where $\mathrm{A}$ is a dose difference between 2 successive doses, B the mean of dead fish between 2 successive doses and $\mathrm{N}$ the total number of fish. Then about 100 male $O$. niloticus were divided into 5 groups, distributed among 10 glass aquaria each of 50 x 20 x $100 \mathrm{~cm}$ with 100 liter capacity. 10 fish each (2 aquaria for each group). One group (20 fish) kept as control and the other four groups were subjected to 1/10 LC50 of phenol concentration. Samples were taken after 21, 28, 35 and 45 days. The water within aquaria was fully drained daily then a maintenance dose (the same experimental dosage) of phenol was added to avoid any possible degradation of phenol during the 45 days course of experiment (Gaur et al., 2016). Dissolved oxygen (DO) was $5.4 \pm 0.3 \mathrm{mg} / \mathrm{l}$ and PH was $7 \pm 0.3$. were measured according to Clesceri et al., (1989). Throughout the experimental work fish were under full supervision to register any abnormal behavior or external signs according to Amlacher (1970).

\section{Milt and serum collection}

Fish were anesthetized by using $40 \mathrm{mg}^{-1}$ clove oil to avoid stress (Panthukumphol, 2017), then total body length (T.B.L in $\mathrm{cm}$ ) and body weight (B.W in $\mathrm{g}$ ) were measured. Milt collection occurred manually by striping milt in clean and dry tube after drying genitals well to avoid milt contamination with urine, faeces, mucus and water then by gentle abdominal massage milt were exuded (Billard et al., 1995). It was collected using $1 \mathrm{ml}$ syringe. Blood sampling from caudal vein of each fish separately collected in test tubes, centrifuged at $4000 \mathrm{rpm}$ for $10 \mathrm{~min}$ then serum was collected in microfuge tubes at $-20{ }^{\circ} \mathrm{C}$ until needed for analysis (Ando et al., 1986). Also for each fish growth measurements; morph-anatomical parameters; relative fecundity; sperm density and live $/$ dead $\%$ were estimated.

\section{Growth Measurements}

Total body length (T.B.L.) were measured from tip of the snout till the end of the tail. Body weight (B.W.), Gonadal weight (WG) and hepatic weight (WH) were measured by digital balance for each fish separately. 


\section{Morpho-anatomical Parameters}

For each fish gonado-somatic index (GSI) and hepatosomatic index (HSI) were the percentage of gonadal and hepatic weight to that of fish weight according to Coward and Bromage (1998).

$$
\begin{aligned}
& \text { GSI = } 100 \mathrm{WG} / \mathrm{B} . \mathrm{W}-\mathrm{WG}, \\
& \text { HSI = } 100 \mathrm{WH} / \mathrm{B} . \mathrm{W}-\mathrm{WH}
\end{aligned}
$$

As well, the condition factor $(\mathrm{K})$ were calculated to assess fish condition where the higher value of $\mathrm{k}$, the good fish condition, according to Sun and Pankhurst (2004).

$\mathrm{K}=$ B.W $/$ T.B.L. ${ }^{3} \mathrm{X} 100$

\section{Relative Fecundity Estimation}

Relative Fecundity was estimated relatively to the total body length, body weight according to Babiker and Ibrahim (1979).

Related to T.B.L. as F.B.L. $=2.895 \mathrm{~L}^{2.017}$

Related to B.W. as F.B.W. $=16.12 \mathrm{~W}^{0.83}$

\section{Reproductive performance}

Sperm density was calculated according to Caille et al., (2006) by adding a drop of diluted sperm with $0.7 \% \mathrm{NaCl}$ onto a haemocytometer slide with $1 \mathrm{~mm}$ depth, then a coverslip was added and left it until the movement of spermatozoa stopped before counting the number of sperm $\mathrm{ml}^{-1}$ in 16 scales.

The percentage of live and dead sperm were calculated by mixing $10 \mu$ of milt with 10 $\mu l$ of eosin-Y stain on a microscope slide covered with coverslip then counted a total 100 spermatozoa within 2 min after staining where unstained sperm (live) and pink or red colored sperm (dead) according to Zilli et al., (2004).

\section{Sex hormones determination}

Serum concentrations of testosterone and $17 \beta$ estradiol hormones were measured for each fish by the enzyme-linked immunosorbent assay (ELISA) using kits according to Tietz (1995).

\section{Electrophoresis}

Buffer, reagents and equipment used for serum protein (Vitellogenin) preparation and sodium dodecyl sulphate-polyacrylamide gel electrophoresis (SDS-PAGE) measured by electrophoresis method according to Bollage et al., (1996) using Sigma protein marker.

\section{Pathological studies:}

Tissue samples from liver and testis were collected immediately from naturally polluted, treated and control male fish groups then they were fixed in Davidson's altered solution, at that point dried out through ascending concentrations line of ethanol, cleared with xylene solutions, inserted and obstructed in paraffin wax according to Genten et al. (2009). Fine transverse segments $5 \mu$ were cut, put on and stained with hematoxylin and eosin according to Johnson et al. (2010). 


\section{Statistical analysis}

All obtained data were statistically analyzed by using independent samples t-test according to McDonald J.H. (2008), using Microsoft Excel. In all suits, significance was accepted at $(\mathrm{P}<0.001)$.

\section{Ethical Statement}

The current study was approved by the Ethical Committee for live fish sampling at the Animal Health Research Institute, Egypt (License No. AHRI 35429).

\section{RESULTS AND DISCUSSION}

In the naturally polluted Oreochromis niloticus group, phenol level in liver was 1.4 ppm and was $0.02 \mathrm{ppm}$ in water while Moustafa et al., (2007) had reported the phenol level in water samples from Helwan was $0.42 \mathrm{mg} / \mathrm{l}$. Experimentally the LC50 of phenol was determined to be $(30 \mathrm{mg} / \mathrm{l})$ for $96 \mathrm{hrs}$. in $O$. niloticus fish of body weight $100 \pm 20 \mathrm{~g}$. which was less than Moustafa et al. (2007) who calculated it to be $25 \mathrm{mg} / \mathrm{l}$ for same fish from Helwan (Nile River)with body weight $90 \pm 10 \mathrm{~g}$. this difference may be due to the body weight variation. Cultured male Oreochromis niloticus were exposed to (1/10 LC50) chronic or long term exposure for 45 days, a daily examination showed stop feeding, loss of reflexes, sunken eyes, scale lose, darkening skin, with fins and tail rot (Figure 1b), nervous manifestation and death at the final days of experimental period.

(a)

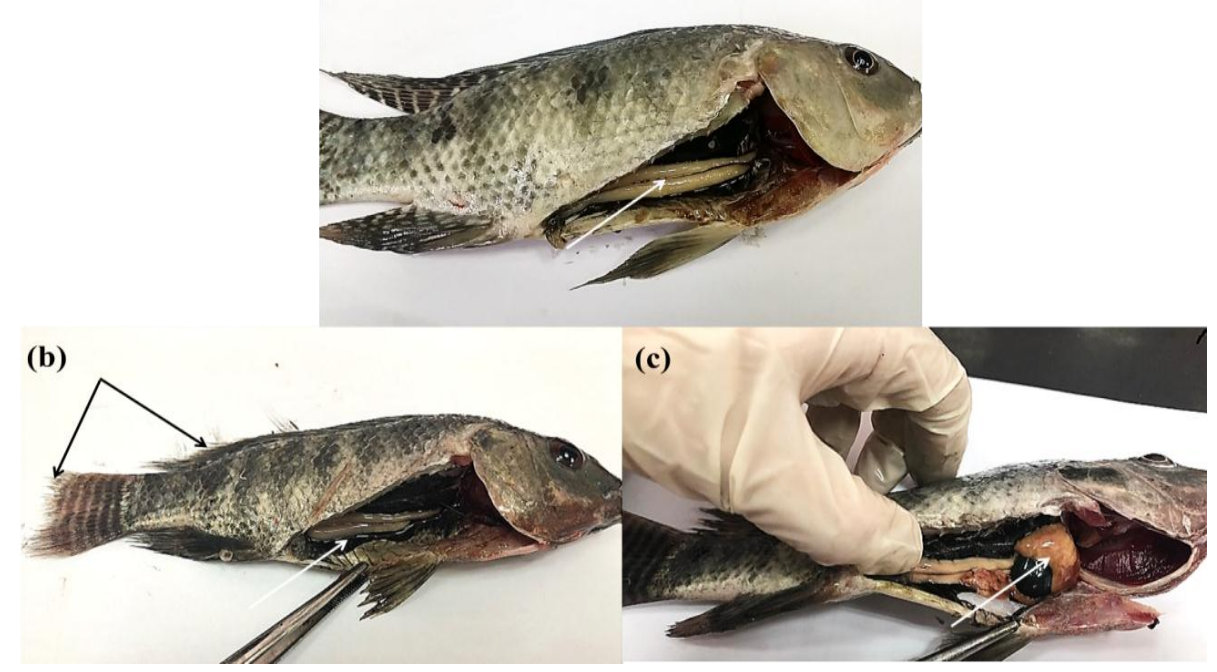

Figure 1. (a) macroscopic examination of control male Nile tilapia showed symmetric testis. (b) treated male Nile tilapia with phenol for 45 days showed dark skin with fin, tail rot and asymmetric testis. (c) liver showed pale patch.

These clinical signs appeared in accordance with Mai (2012) in Clarias gariepinus fish which might be referred to the neuronal changes rose from the gill irritations caused by phenol. The most important postmortem changes were detected within the last periods 35 and 45 days. Where mortality rate has begun low and increased with increase of exposure duration reaching $40 \%$ (Table 1 ). 
Table 1. Morality rate during the phenol experimental toxicity

\begin{tabular}{llll}
\hline $\begin{array}{l}\text { Experiment } \\
\text { periods }\end{array}$ & $\begin{array}{l}\text { Number of } \\
\text { fish }\end{array}$ & $\begin{array}{l}\text { Number of } \\
\text { dead fish }\end{array}$ & $\begin{array}{l}\text { Mortality } \\
\text { rate \% }\end{array}$ \\
\hline Control & 20 & 1 & 5 \\
21 days & $r_{0}$ & 2 & 1. \\
28 days & $r_{0}$ & $r$ & 10 \\
35 days & $r_{0}$ & 0 & ro \\
45 days & $r_{0}$ & $\wedge$ & $\varepsilon \cdot$ \\
\hline
\end{tabular}

Primary reproductive investment is represented by gonadal weight and gonadosomatic index which is an indicator of somatic and reproductive measurement of mature fish (Malavasi et al. ، 2004). Moreover, phenol pollution, in this study revealed significant drop in testicular weight (WG) and gonado-somatic index (GSI) in males throughout the experimented period in table (2). This was agreed with Zaroogian et al., (2001) and Wang et al., (2018) who proved that Octylphenol and nonylphenol resulted in reduced testicular growth in summer flounder (Heiculter leucisculus) respectively, decreasing in (GSI) indicated impairment of steroidogenesis in catfish exposed to phenol (Das et al., 2018). Also, the significant drop in testicular weight (WG) and gonado-somatic index (GSI) among males experimentally exposed to phenol for 45 days came in accordance with asymmetric testis was shown in figure $1 \mathrm{~b}$ and the significant drop in sperm density in experimentally exposed (Table 2), which was approved by Wang et al., (2018) who proved spermatogenesis suppression influenced by nonylphenol. Pathological examination in this study, revealed evacuated testicular lumen with complete absence of spermatogonia. Also the percent of live sperms was significantly dropped were assisted by testis showing remnants of degenerated spermatocytes associated with scant number of sperms and marked increase of inter-lubular fibrous connective tissue (Figure 5f) Consequently, the microscopic examination of treated milt showed a lot of dead sperms (stained) with eosin-Y stain (Figure 2b).

Also, Ismail and Mahboub (2016) showed few spermatozoa in O. niloticus exposed to nonylphenol. The significant drop only in total protein among the experimentally exposed males $O$. niloticus after 21, 28 and 35 days (Table 3) where Remya (2010) explained that under stress tissue protein undergo proteolysis resulting in amino acids production used by fish for energy production. In agreement, Sannadurgappa et al., (2011) found a greatly drop in total protein of $O$. mossambicus under phenol acute toxicity. Albumin registered significant increase in males after all experimented periods (Table 3), this could be explained according to Baker (2002) by the induction of albumin synthesis in spawning time because it plays an important role in transport function of various components needed for gonads formation. Hager and Heba (2016) also proved that nonylphenol caused significant increase in albumin of O. niloticus. On the contrary, Monfared and Salati (2013) found that phenol caused drop of albumin in rainbow trout. However, in this research, the male $O$. niloticus had registered highly significant decrease in globulin 
among experimented (after 21, 28 and 35 days) (Table 3), which might be due to the immunosuppressant action of phenol according to Dunier and Siwicki (1993).

Table 2. Growth measurements, morpho-anatomical parameters, relative fecundity and reproductive performance of male Oreochromis niloticus at the different experimental periods of phenol toxicity.

\begin{tabular}{|c|c|c|c|c|c|c|}
\hline \multicolumn{2}{|c|}{ Reproductive parameter } & Control & $\begin{array}{l}\text { After } \\
21 \text { days }\end{array}$ & $\begin{array}{c}\text { After } \\
28 \text { days }\end{array}$ & $\begin{array}{l}\text { After } \\
35 \text { days }\end{array}$ & $\begin{array}{l}\text { After } \\
\mathbf{4 5} \text { days }\end{array}$ \\
\hline \multirow{4}{*}{$\begin{array}{l}\text { Growth } \\
\text { Measurements }\end{array}$} & $\begin{array}{l}\text { T.B.L } \\
(\mathrm{cm})\end{array}$ & $21 \pm 0.7$ & $18.2 \pm 0.2$ & $19.2 \pm 0.3$ & $19 \pm 0.3$ & $18.4 \pm 0.2$ \\
\hline & B.W (g) & $117 \pm 1$ & $82.6 \pm 2 *$ & $\begin{array}{l}89.8 \\
3.1 *\end{array} \quad \pm$ & $97.2 \pm 2 *$ & $83.6 \pm 3^{*}$ \\
\hline & WH (g) & $3.3 \pm 0.1$ & $1.4 \pm 0.1 *$ & $\begin{array}{l}1.16 \\
0.1 *\end{array} \quad \pm$ & $\begin{array}{l}1.72 \\
0.1 *\end{array} \quad \pm$ & $1.4 \pm 0.1^{*}$ \\
\hline & WG (g) & $3.5 \pm 0.2$ & $0.8 \pm 0.1^{*}$ & $0.9 \pm 0.1 *$ & $\begin{array}{l}0.68 \\
0.1 *\end{array} \quad \pm$ & $\begin{array}{l}0.32 \\
0.04 *\end{array} \quad \pm$ \\
\hline \multirow{3}{*}{$\begin{array}{l}\text { Morpho- } \\
\text { anatomical } \\
\text { Parameters }\end{array}$} & GSI (\%) & $1.8 \pm 0.2$ & $1.6 \pm 0.2$ & $1.16 \pm 0.2$ & $\begin{array}{l}0.72 \pm 0.1 \\
*\end{array}$ & $\begin{array}{ll}0.38 & \pm \\
0.04 * & \end{array}$ \\
\hline & HIS (\%) & $1.3 \pm 0.1$ & $1.6 \pm 0.1$ & $1.44 \pm 0.2$ & $\begin{array}{l}1.68 \quad \pm \\
0.2\end{array}$ & $1.74 \pm 0.1$ \\
\hline & $\mathrm{K}$ & $1.6 \pm 0.1$ & $1.3 \pm 0.1$ & $1.3 \pm 0.1$ & $\begin{array}{l}1.22 \\
0.02\end{array}$ & $1.36 \pm 0.01$ \\
\hline \multirow{2}{*}{$\begin{array}{l}\text { Relative } \\
\text { Fecundity }\end{array}$} & FBL & $1251 \pm 4$ & $1008.8 \pm 3^{*}$ & $1182.2 \pm 2$ & $1223.4 \pm 5$ & $1020.2 \pm 3 *$ \\
\hline & FBW & $880 \pm 3$ & $635 \pm 1 *$ & $634 \pm 1^{*}$ & $712 \pm 2 *$ & $633.6 \pm 2 *$ \\
\hline \multirow{3}{*}{$\begin{array}{l}\text { Reproductive } \\
\text { performance }\end{array}$} & $\begin{array}{l}\text { Sperm } \\
\text { Density/ } \\
\mathrm{ml}\end{array}$ & $2442 \pm 2$ & $1698 \pm 3$ & $\underset{*}{1576 \pm 8}$ & $759 \pm 5 *$ & $430 \pm 1 *$ \\
\hline & Live $\%$ & $84 \pm 4$ & $58.2 \pm 3 *$ & $67 \pm 4$ & $\begin{array}{l}35.6 \\
0.8^{*}\end{array}$ & $20.8 \pm 6^{*}$ \\
\hline & Dead \% & $16 \pm 1$ & $41.8 \pm 3 *$ & $33 \pm 4 *$ & $\begin{array}{l}64.4 \\
0.8^{*}\end{array}$ & $79.2 \pm 1$ \\
\hline
\end{tabular}

Note: $\mathrm{n}=10 * \mathrm{P}<0.001$

T.B.L, total length; BW, body weight; WH, hepatic weight; WG, gonadal weight; GSI, gonadosomatic index; HSI, hepato-somatic index; K, condition factor; FBL, fecundity related to the total body length; FBW, fecundity related to body weight. 


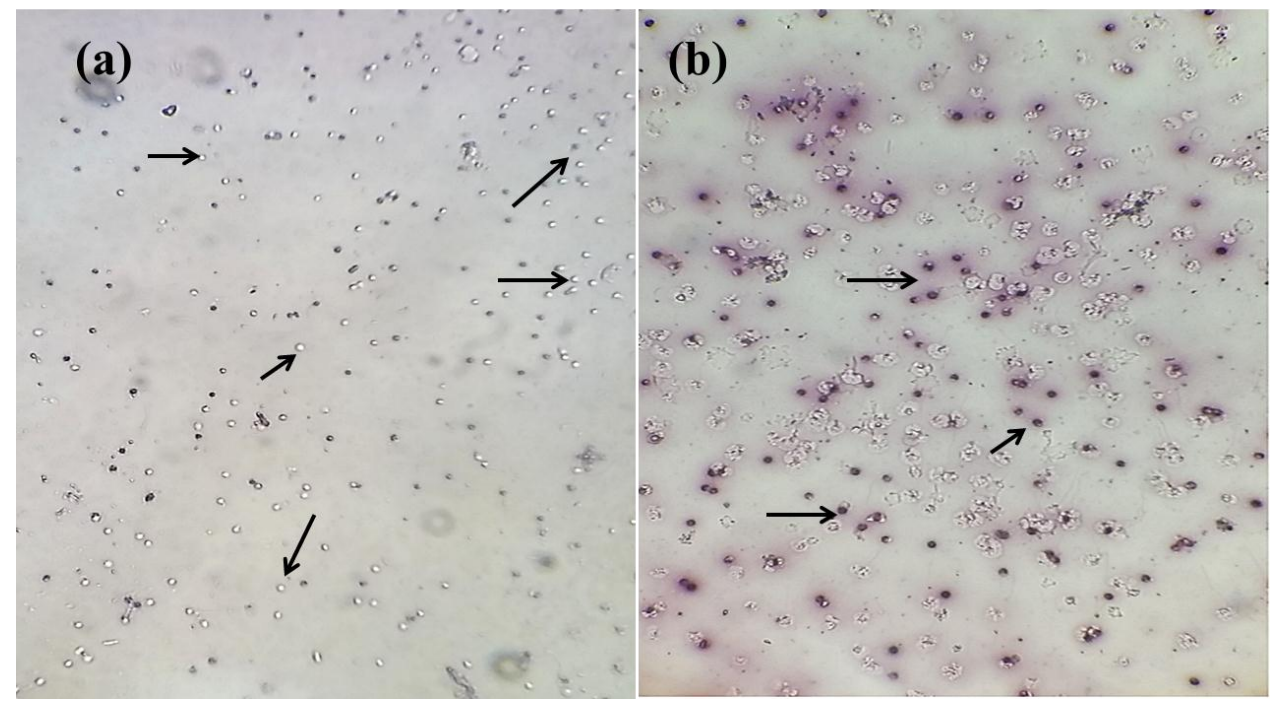

Figure 2. (a) microscopic examination of control milt showed living sperms (unstained) 40x. (b) milt of treated Nile tilapia with phenol showed a lot of dead sperms (stained) with eosin-Y stain $(40 x)$.

Glucose level registered significant increase in male $O$. niloticus during experimentally periods (Table 3). Glucose increase as a secondary physiological response for energy use which is involved in innate defense mechanism according to Zeynep et al., (2017). Phenol also increased glucose level in Labeorohita (Gaur et al., 2016). Oppositely, Remya (2014) proved phenol pollution causing drop of glucose as a result for the inhibition of the synthesis of blood glucose regulating hormone. Alanine aminotransferase (ALT) in the experimented males $O$. niloticus recorded significant increase (Table 3), which might be referred to that ALT are normally found in low concentrations in blood, whereas if liver cells are damaged, they may leak them into the plasma or serum causing an increase in catalytic activity (Heath,1987).

That was proved with marked vacoulation and massive necrosis of hepatocytes embedded in undifferentiated stroma (Figure 4b) after 35 days of exposure. Aspartate aminotransferase (AST) enzyme in this research, among treated fish showed a general trend to decrease when compared to the control values (Table 3), This might be explained by liver enzyme inhibition influenced by pollutant effect (phenol), and/or disturbances in Krebs cycle (Salah El-Deen et al., 1993). This was approved by marked vacuolation of hepatocytes with intra vascular thrombus formation others revealing mild dilation of hepatic sinusoids, with large focal aggregation of melano-macrophage (Figure 4c, d) after 45 days of exposure. 
Table 3. Biochemical parameters of male Oreochromis niloticus at the different experimental periods of phenol toxicity.

\begin{tabular}{|c|c|c|c|c|c|}
\hline $\begin{array}{l}\text { Biochemical } \\
\text { parameters }\end{array}$ & Control & $\begin{array}{l}\text { After } \\
\text { 21days }\end{array}$ & $\begin{array}{l}\text { After } \\
28 \text { days }\end{array}$ & $\begin{array}{l}\text { After } \\
35 \text { days }\end{array}$ & $\begin{array}{l}\text { After } \\
\text { 45days }\end{array}$ \\
\hline $\begin{array}{l}\text { Total protein } \\
(\mathrm{g} / \mathrm{dl})\end{array}$ & $7.2 \pm 0.3$ & $3.9 \pm 0.2^{*}$ & $4.5 \pm 0.3^{*}$ & $1.6 \pm 0.1^{*}$ & $8.7 \pm 0.3^{*}$ \\
\hline $\begin{array}{l}\text { Albumin } \\
\text { (g/dl) }\end{array}$ & $\begin{array}{ll}0.5 & \pm \\
0.01 & \end{array}$ & $0.9 \pm 0.1 *$ & $0.9 \pm 0.1^{*}$ & $1.1 \pm 0.1^{*}$ & $1.0 \pm 0.1^{*}$ \\
\hline $\begin{array}{l}\text { Globulin } \\
\text { (g/dl) }\end{array}$ & $6.6 \pm 0.3$ & $3.1 \pm 0.2^{*}$ & $3.5 \pm 0.4^{*}$ & $0.6 \pm 0.2^{*}$ & $7.6 \pm 0.4$ \\
\hline $\operatorname{ALT}(\mathrm{g} / \mathrm{dl})$ & $9.6 \pm 0.3$ & $25.4 \pm 1.4^{*}$ & $18.3 \pm 0.7 *$ & $18.6 \pm 1.1 *$ & $16.8 \pm 0.9 *$ \\
\hline $\operatorname{AST}(\mu / \mathrm{ml})$ & $43.1 \pm 4$ & $25.4 \pm 1.4$ & $16.4 \pm 0.9 *$ & $11.4 \pm 0.6^{*}$ & $16.8 \pm 0.9 *$ \\
\hline $\begin{array}{l}\text { Glucose (mg/d } \\
\text { 1) }\end{array}$ & $28 \pm 0.4$ & $59.2 \pm 2.3^{*}$ & $56.6 \pm 1.1^{*}$ & $63.2 \pm 2.7 *$ & $58.8 \pm 2.4^{*}$ \\
\hline $\begin{array}{l}\text { Estradiol (ug / } \\
\mathrm{ml} \text { ) }\end{array}$ & $705 \pm 2$ & $1102 \pm 2 *$ & $1100 \pm 2 *$ & $589 \pm 3 *$ & $987 \pm 1 *$ \\
\hline $\begin{array}{l}\text { Testosterone } \\
(\mathrm{pg} / \mathrm{ml})\end{array}$ & $\begin{array}{l}16.7 \quad \pm \\
0.3\end{array}$ & $17.82 \pm 0.1$ & $17.98 \pm 0.1$ & $18.46 \pm 0.1^{*}$ & $\begin{array}{l}18.26 \\
0.1^{*} \\
\end{array}$ \\
\hline
\end{tabular}

Note: $\mathrm{n}=10 * \mathrm{P}<0.001$

ALT, alanine aminotransferase; AST, aspartate aminotransferase. 


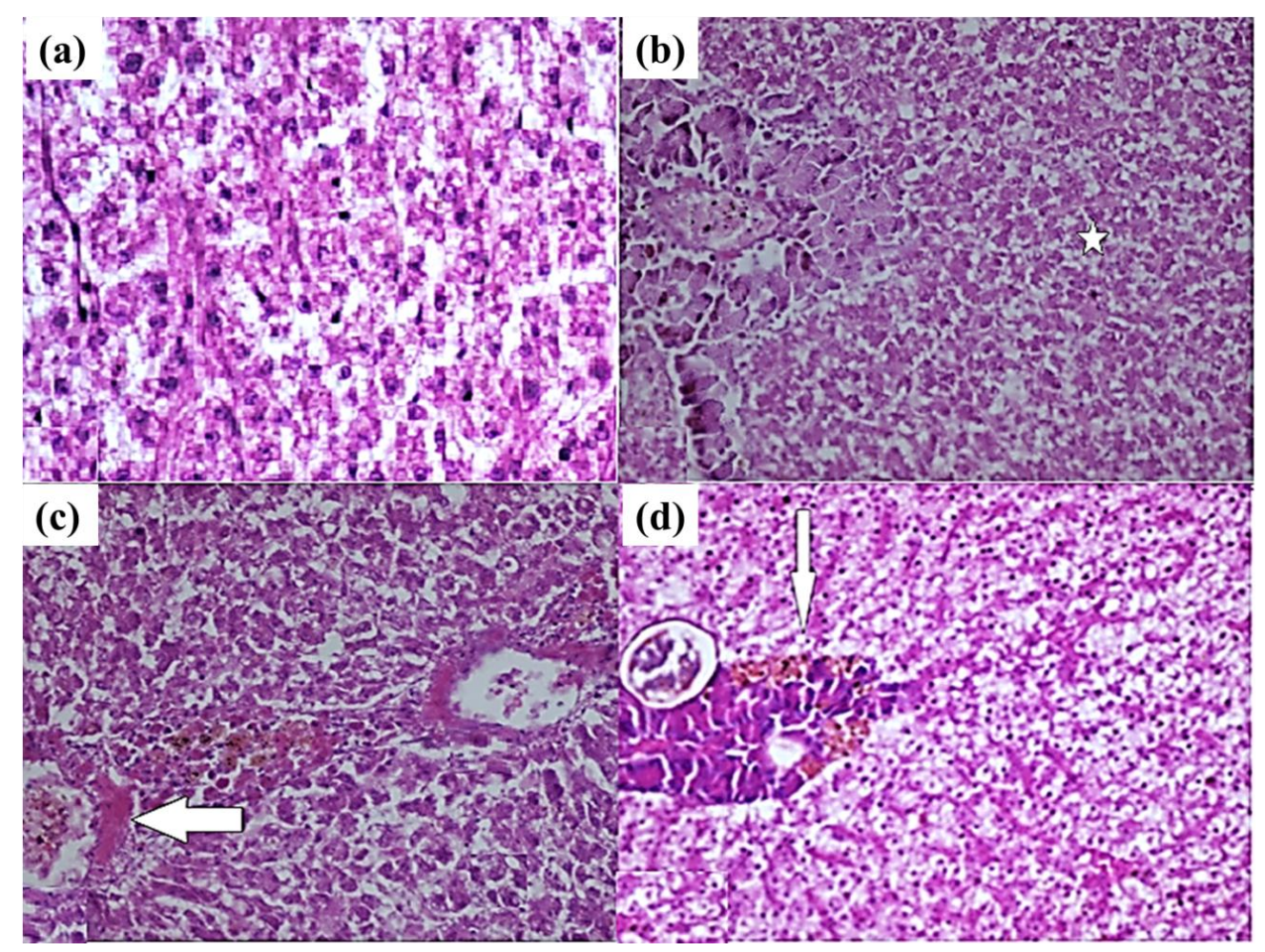

Figure 3. (a) liver of control male $O$. niloticus revealing normal architecture of hepatic parenchyma. (b) naturally polluted Oreochromis niloticus with phenol showed features of hepatocytes coagulative necrosis associated with infiltration of fibrinous exudates, and (c) showed thickening and dilation of hepatic vein. (d) after 28 days of phenol exposure hepatic parenchyma showed moderate infiltration of melano-macrophage around hepato-panceatic structure (200x).

Tang et al. (2017) had defined Estrogen receptors are expressed in male fish, and the testis is one major site of expression, suggesting that estrogens are involved in regulating reproduction in males so, the significant increase in $17 \beta$-estradiol in males experimentally exposed to phenol after 21, 28 and 45 days (Table 3) proved that phenol is an endocrine disruptor chemical and that affect testis showing evacuated testicular lumen with complete absence of spermatogonia and remnants of degenerated spermatocytes associated with scant number of sperms and marked increase of inter-tubular fibrous connective tissue associated with narrowing of testicular tubular lumen (Figure 5f). In addition, Senarat et al. (2017) admitted a relationship between pollutants and this hormone rise. This is consistent with testis of naturally polluted group revealed number of testicular tubules showing features of degeneration in the form of pyknotic and sloughed spermatocytes with complete loss of spermatogenic content (Figure 5b). 


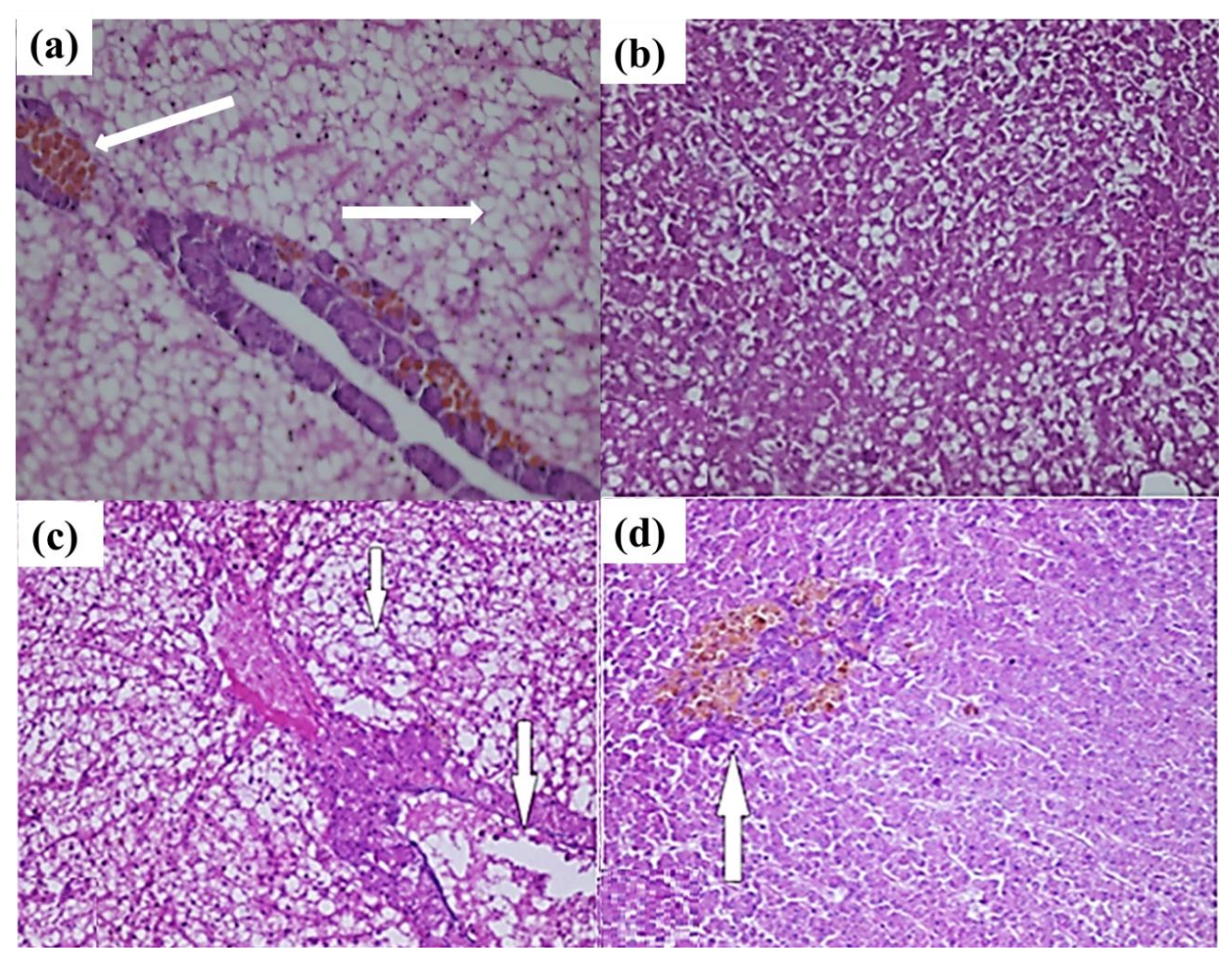

Figure 4. (a) after 35 days of exposure showed moderate infiltration of melano-macrophage around hepato-pancreatic structure with marked vacuolation of hepatocytes (400x). (b) large sized vacuoles with massive necrosis of hepatocytes (200x). (c) after 45 days revealing marked vacuolation of hepatocytes with intravascular thrombus formation (400x). (d) mild dilation of hepatic sinusoids, with large focal aggregation of melano-macrophage (400x).

Rahma (2015) results of electrophoresis proved appearance of vitellogenin from plasma of male O.niloticus as chronic exposure to Thiobencarb at band $440 \mathrm{~K} \mathrm{Da}$ where its raw volume increased from $7006 \mathrm{mg} / \mathrm{dl}^{3}$ to $17881 \mathrm{mg} / \mathrm{dl}^{3}$ after 7 and 14 days exposure respectively. In this study, electrophoretic analysis of serum for vitellogenin revealed appearance of two bands in protein marker at 440 and $654 \mathrm{~K}$ Da respectively. In males $O$. niloticus experimentally exposed to phenol, the first band appeared after 21, 28 and 35 days (Figure 6). This was approved by the significant increase in $17 \beta$-estradiol levels throughout the experiment (Table 3), which was explained by the action of phenols being endocrine disruptor chemicals, estrogenic compounds, so-called environmental estrogen (xenoestrogen) via binding to estrogen receptors in Chinese minnow hepatocytes (Park et al.,2003). In addition, this result came in agreement with the significant drop of sperm density (Table 2). Concerning the second band which was characterized as female specific appeared in male O.niloticus serum only after 45days (Figure 6). That was confirmed by testis after 45 days showed testicular lumen evacuated with complete absence of spermatogonia and remnants of degenerated spermatocytes associated with scant number of sperms (Figure 5f). 


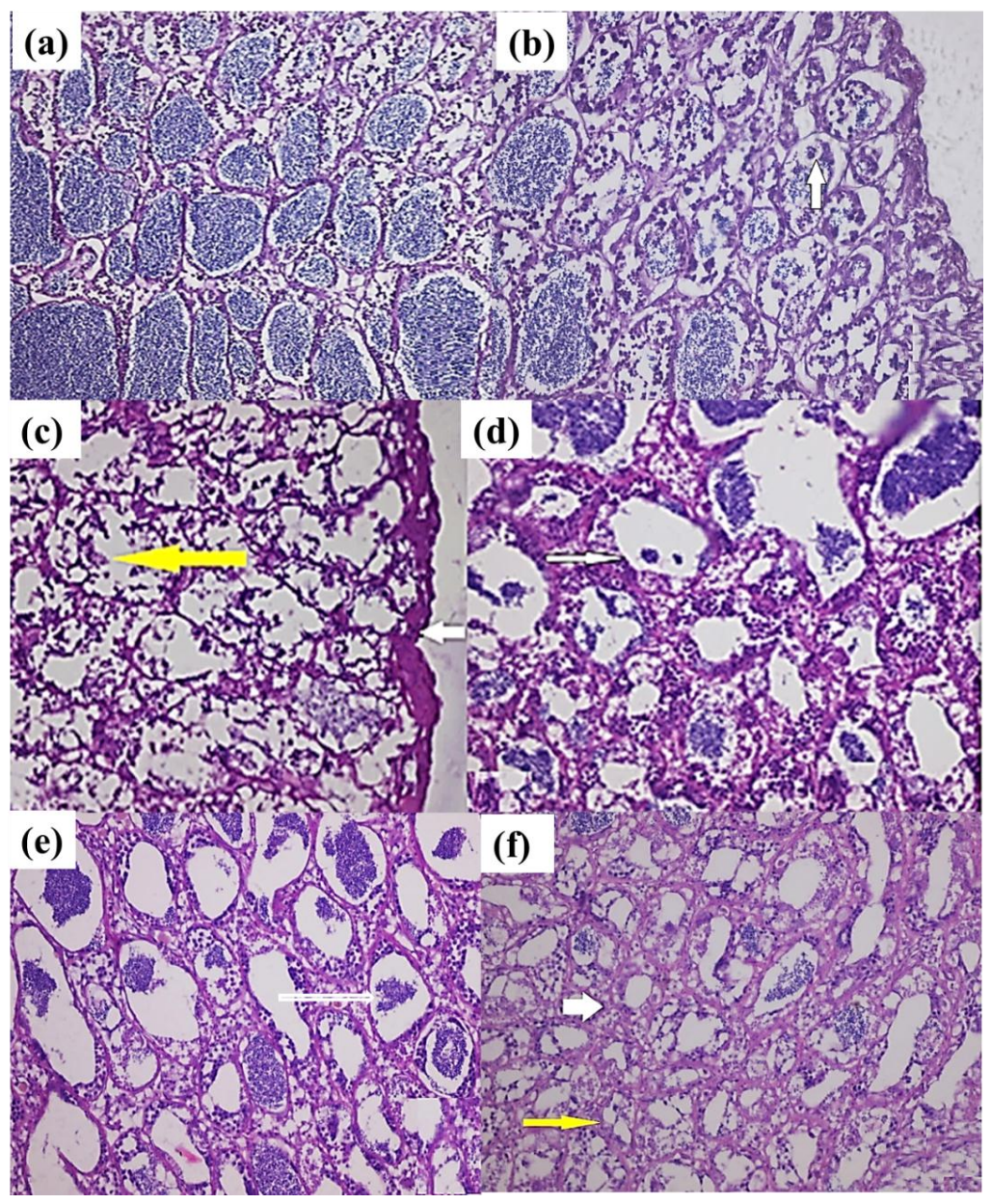

Figure 5. (a) histopathological investigation of control $O$. niloticus testis revealing normal criteria of testicular tubules with high content of spermatids (b) testicular tubules of naturally polluted fish showed pyknotic and sloughed spermatocytes with complete loss of spermatogenic contents. (c) testis after 21 days showing marked thickening of tunica albuginea associated with severely degenerated testicular tubules and absence of its components. (d) after 28 days showed complete absence of spermatoginea with degenerated spermatocytes and spermatids, with variable numbers of sperms within the testicular tubular lumen. (e) after 35 days depletion of spermatogonia with moderate preservation of spermatocytes, spermatids and sperms. (f) after 45 days testicular lumen evacuated with complete absence of spermatogonia and remnants of degenerated spermatocytes and marked increase of inter-tubular fibrous connective tissue associated with narrowing of testicular tubular lumen (200x). 


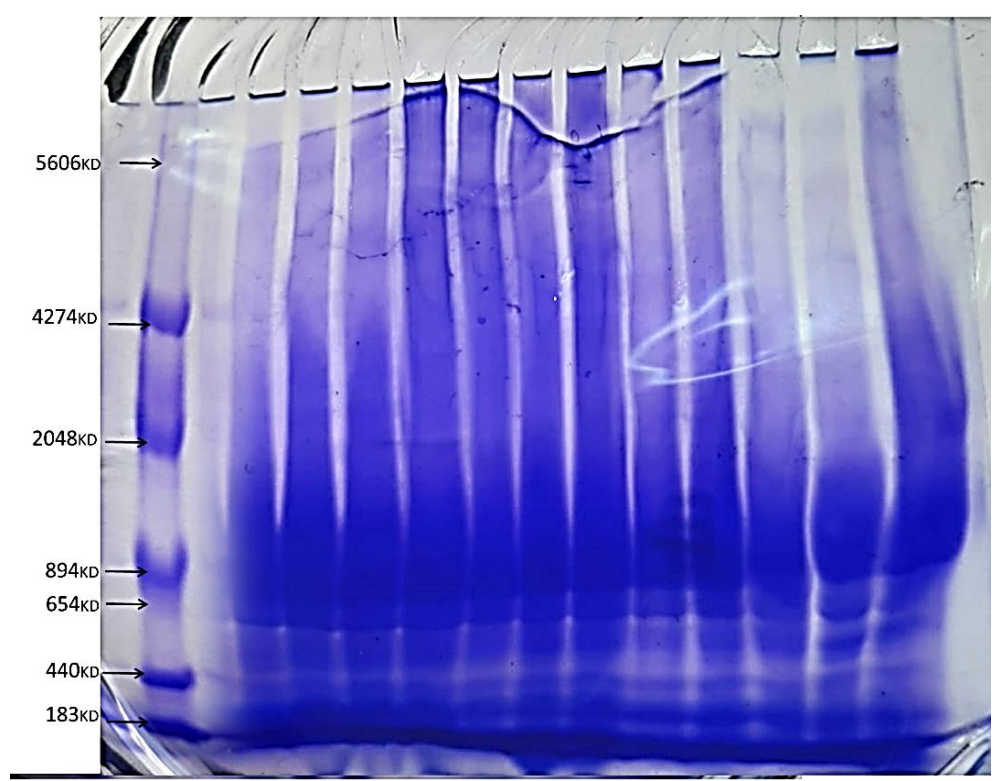

Figure 6. Gel of electrophoresis for vitellogenin investigation

\section{CONCLUSION}

It is concluded that phenols, being one of the most dangerous endocrine disruptor chemicals exerting drastic effects on male $O$. niloticus fish growth measurements, relative fecundity, reproductive performance and biochemical parameters in experimentally and naturally polluted groups. Moreover, phenols acting as estrogenic compounds resulted in highly significant increase in Estradiol level throughout the experimental periods together with the appearance of vitellogenin in male testis at the different experimental periods. To sum up, the protection of fish farms' water supply from being polluted with endocrine disrupting chemicals is highly mandated to ensure sustainable aquaculture.

\section{ACKNOWLEDGMENT}

We would like to thanks Prof. Naglaa M. AL-Kalamaw, Department Of Pathology, Molecular Pathology Unit, Animal Health Institute for her valuable support in histopathological investigation.

\section{REFERENCES}

Abdel-Hameid, A.H. (2007). Physiological and Histopathological Alterations Induced by Phenol Exposure in (Oreochromis aureus) Juveniles. Turkish Journal of Fisheries and Aquatic Sciences 7: 131-138.

Amlacher, E. (1970). Textbook of fish diseases. Jersey City: TFH Publications Inc.

Ando, S.; Takeyama, T. and Hatano, M. (1986). Transport Associated with Serum Vitellogenin of Carotenoid in Chum Salmon (Oncorhynchusketa). Journal of Agriculture and Biological Chernistry, 50 (3): 557-563.

Andrew, F.R. (1990).Techniques in fish immunology, SOS Publication, 43 De 
Normandie Ave, Fair Haven, NJ 07704-3303 U.S.A, 113-136.

Babiker, M. M. and Ibrahim, H. (1979). Studies on the biology of reproduction in the cichlid Tilapia Nilotica (L): gonadal maturation and fecundity. Journal of Fish. Biology, 14:437-448.

Baker, M.E. (2002). Albumin ,steroid hormones and the origin of vertebrates . Journal of Endocrinology 175: 121-127.

Barakat, A.O. (2004). Assessment of persistent toxic substances in the environment of Egyptian Environmental International, 30: 309-322.

Billard, R.; Cosson, J.; Crim, L.W. and Suquet, M. (1995). Broodstock management and seed quality-General considerations. In: Bromage N, Roberts RJ (Eds.). Broodstock management and egg larval quality. Oxford: Blackwell Science pp. 1: $24-27$.

Bin-Dohaish, A.E. (2010). Effect of Environmental pollutants (4-nonylphenol) On gonads and sex steroids of tilapia (Oreochromus spilurs) in Jeddah .proc of the 3rd global fisheries and aquaculture research conference . foreign agriculture relations (FAR) pp. 268-288.

Bollage, D.M.; Rozycki, M.D. and Edelstein, S.J. (1996)." Protein Method , 2 nd Ed., Willey Liss.

Caille N.; Rodina M.; Kocour M.; Gela D.; Flajshans M. and Linhart O. (2006). Quantity, motility and fertility of tench Tinca tinca (L.) sperm in relation to LHRH analogue and carp pituitary treatments. Aquac. Int. 14: 75-87.

Clesceri, L.; Greenberg, A. and Trussell, R. (1989). Standard methods for the examination of water and waste water. 17th ed. Washington, DC: American Public Health Association.

Coward, K., and Bromage, N. R. (1998). Histological classification of oocyte growth and the dynamics of ovarian recrudescence in Tilapia zilli. Journal Fish Biology, 53: 285-302.

Das, S.; Majumder, S. and Mukherjee, D. (2013).Effect of Phenol on Ovarian Secretion of $17 \beta$-Estradiol in Common Carp (Cyprinus carpio), Archives of Environmental Contamination and Toxicology July, 65(1):132-141.

Das, M.K.; Samanta, S.; Saha, K.; Bhowmick, S.; Srivastava, K. P. and Bandopadhyay, S. (2018). Effect of phenol and sulphide on the reproduction of sexually maturing riverine cat fish Rita rita (Hamilton). Journal Inland Fish. Soc. India, 50 (2): 52-57.

Deichmann, W. and Scott, W. E. (1939). Quantitative Estimation of Phenol and Related Compounds in Tissues, Industrial and Engineering Chemistry Research, 11(8): 423-424.

Dunier, M. and Siwicki, A.K. (1993). Effects of pesticides and other organic pollutants in the aquatic environment on immunity of fish: a review. Fish Shellfish Immunology, 3: 423-438.

Eissa, A.E.; Moustafa, M.; El-Husseiny, I.N.; Saeid, S.; Saleh, O. and Borhan, T. (2009). Identification of some skeletal deformities in freshwater teleost raised in Egyption Aquaculture, Chemosphere, 77: 419-425.

Eissa, A.E.; Tharwat, N.A. and Zaki, M.M. (2013). Field assessment of the mild winter mass kills of trophic fishes at Mariotteya stream, Egypt: Chemical and biological pollution synergistic model, Chemosphere, 90: 1061-1068.

El-Ashtoukhy, S.Z.; EL-Taweel, Y.A.; Abdelwahab, O. and Nassef, E.M. (2013).

Treatment of petrochemical wastewater containing phenolic compounds by 
electrocoagulation using a fixed bed electrochemical reactor. International Journal Electrochemical Science, 8: 1534-1550.

Food and Agriculture Organization (FAO) (1983). World review of the situation in Sub-Saharan Africa Women in developing agriculture, No 16.

Gaur, V.; Raina, V.; Jain, R. and Mathur, A. (2016). Effect of phenolic compounds on the metabolic profile of Labeorohita. International Journal of Pharma and Biology Sciences, 10: 101-115.

Genten, F.; Terwinghe, E. and Danguy, A. (2009). Atlas of Fish Histology, 1st Ed., pp. 219, Science Publishers, Enfield, NH, USA.

Goulden, P.D.; Brooksbank, P. and Day, B. (1973). Determination of sub-microgram levels of phenol in water. Analytical chemistry, 4(14): 2430-2433.

Hager, H. I. and Heba, H. M. (2016). Effect of acute exposure to nonylphenol on biochemical, hormonal, and hematological parameters and muscle tissues residues of Nile tilapia (Oreochromisniloticus).Veterinary World, 9(6): 616-625.

Heath, A.G. (1987). Water pollution and fish physiology. CRC Press Inc. Boca Raton, Florida.

Hecker, M.; Tyler, C.R.; Hoffmann, M.; Maddix, S. and Karbe, L. (2002).Plasma biomarkers in fish provide evidence for endocrine modulation in the Elbe river, Germany. Environmental Science and Technology, 36: 2311-2321.

Hori, T.S.F.; Avilez, I.M.; Inoue, L.K. and Moraes, G. (2006).Metabolical changes induced by chronic phenol exposure in Matrinxã bryconcephalus (teleostei: characidae) juveniles. Comparative Biochemistry and Physiology, 143(1): 67-72.

Ismail, H.T.H. and Mahboub, H.H.H. (2016). Effect of acute exposure to nonylphenol on biochemical, hormonal, and hematological parameters and muscle tissues residues of Nile tilapia (Oreochromis niloticus).Veterinary World, 9(6): 616-625.

Johnson, R.; Wolf, J. and Braunbeck, T. (2010). OECD, Guidance document for the diagnosis of endocrine-related histopathology of fish gonads. Series on Testing and Assessment, No. 123: pp. 114.

Khan, M. Z. and Law, F.C.P. (2005).Adverse effects of pesticides and related chemicals on enzyme and hormone systems of fish, amphibians and reptiles. Proceeding of Pakistan Academy of Science, 42 (4): 315-323.

Kime, D.E. (1999). A strategy for assessing the effects of xenobiotics on fish reproduction. Science Total Environment Journal, 225: 3-11.

Litchfield, J.T. and Wilcoxon, F. (1949).A simplified method of evaluating dose-effect experiments. Journal of Pharmacology and Experimental Therapeutics, 96: 99-113.

Mai, D. (2012). Experimental exposure of African catfish Clarias gariepinus (Burchell, 1822) to phenol: Clinical evaluation, tissue alterations and residue assessment, Journal of Advanced Research, (3): 177-183.

Malavasi, S.; Fiorin, R.; Franco, A. and Torricelli, P. (2004). Somatic energy storage and reproductive investment in the grass goby (Zosterises sorophiocephalus). Journal of Marine Bioloy, Assoc. UK 84: 455-459.

McDonald, J.H. (2008). Handbook of Biological Statistics Sparky House Publishing, Baltimore.

McLachlan, J.A.; Simpson, E. and Martin, M. (2006).Endocrine disrupters and female reproductive health. Best Practical Research Clinical Endocrinology Metabolism, 20 (1): 63-75. 
Michalowicz, J. and Duda, W. (2007). Phenols - Source and toxicity. Pol. Journal of Environmental Studies, 16(3): 347-362.

Moustafa, A.M.; Aly, A.A.; Aly, S.M.; Mesalhy, S.; El-Ghobashy, H.A.; Hasanin, S.I. and Ibrahim, A.E. (2007). Influence of phenol pollution on Nile tilapia Oreochromis niloticus. Egyptian Journal Aquatic Biology and Fisheries, 11: 709-720.

Monfared, A.L. and Salati, A.P. (2013). Histomorphometric and biochemical studies on the liver of rainbow trout (Oncorhynchusmykiss) after exposure to sublethal concentrations of phenol. Toxicological and Health, 29(9): 856-61.

Panthukumphol, N. (2017). Onset and stages of anesthesia in Nile tilapia (Oreochromis niloticus) at different concentration of eugenol. Thai. Journal of Veterinary Medicine Suppl., 47: 287-288 .

Park, B.C.; Kim, H.B.; Choi, C.; Lee, D.Y.; Baek, J.H.; Kim, B.H. and Takemura, A. (2003). Induction of In Vitro Vitellogenin Synthesis by Bisphenol, Nonylphenol and Octylphenol in Chinese Minnow (Phoxinusoxycephalus) Hepatocytes. Korean Journal Biological Science, 7: 227-235.

Remya, V. (2010). Biochemical Effects of different Phenolic compounds on $O$. mossambicus. Ph.D. Thesis. Cochin University of Science and Technology, Cochin. 2010.

Remya, V.; HariSankar, H.S.; Jisha, J. and Babu, P. (2014). Sublethal effects of phenolic compounds on biochemical, histological and iono regulatory parameters in a tropical teleost fish Oreochromis mossambicus (Peters). International Journal of Scientific and Research Publications, 4(3): 2250-3153.

Rhama, H. (2015). Role of thiobencarb in endocrine disruption and reproduction of Oreochromis niloticus. Thesis submitted to Faculty of Veterinary Medicine Suez canal university.

Salah El-Deen, M.A. and Rogers, W.A. (1993). Changes in total protein and transaminase activities of grass carp exposed to diquat. Journal Aquatic Animal Health, 5(4): 280-286.

Sannadurgappa, D.; Ravindranath, N.H. and Aladakatti, R.H. (2011).Toxicity bioaccumulation and metabolism of phenol in freshwater fish Oreochromis mossambicus DE Gurytervol.18, toxicity. Aquaculture Toxicology, 68 (4): 369-392.

Senarat, S.; Jiraungkoorskul, W. and Kettratad, J. (2017). Ovarian histology and reproductive health of short mackerel, Rastrelli gerbrachysoma (Bleeker, 1851), as threatened marine fish in Thailand. Songklanakarin. Journal Science Technology, 39(2): 225-235.

Sun, B. and Pankhurst, N. W. (2004). Patterns of oocyte growth, vitellogenin and gonadal steroid concentrations in greenback flounder. Journal Fish Biology, 64: 1399-1412.

Sun, X.S.; Wu, L.J.; Lv, B.H.; Zhang, Y.H.; Zhang, J.; Qiaoa, F.; Chen, Q.L.; Yang, Y.; Zhang, L.M. and Du, Y.Z. (2020). Environmental estrogen exposure converts lipid metabolism in male fish to a female pattern mediated by AMPK and mTOR signaling pathways. Journal of Hazardous Materials. 394: 122537.

Tang, H.; Yun, L.; Yike, Y.; Gaofei, L.; Yin, G.; Xiaochun, L. and Haoran, L. (2017). New Insights Into the Role of Estrogens in Male Fertility Based on Findings in Aromatase-Deficient Zebrafish, Endocrinology, 158(9, 1,): 3042-3054. 
Tietz, N.W. (1995).Clinical guide to laboratory tests. 3rd ed. Philadelphia: WB Saunders; pp, 268-273.

Tollefsen, K.E.; Eikvar, S.; Finne, E.F.; Fogelberg, O. and Gregersen, I.K. (2008). Estrogenicity of alkylphenols and alkylated non-phenolics in a rainbow trout (Oncorhynchus mykiss) primary hepatocyte culture. Ecotoxicology Environmental Safety,71(2): 370-83.

Wang, S.; Zhu, Z.; He, J.; Yue, X.; Pan, J. and Wang, Z. (2018). Steroidal and phenolic endocrine disrupting chemicals (EDCs) in surface water of Bahe River, China: Distribution, bioaccumulation, risk assessment and estrogenic effect on Hemiculter leucisculus. Environmental Pollution, 243: 103-114. .

World Health Organization (WHO) (1993). Guidelines for Drinking Water Quality, 2nd Ed., Vol. 1, Recommendations, Geneva.

World Health Organization (WHO) (1994). Phenol Health and Safety Guide, Health and Safety Guide No. 88.

World Health Organization (WHO) (2002). Water Pollutants: Biological Agents, Dissolved Chemicals, Non-dissolved Chemicals, Sediments, Heat, WHO CEHA, Amman, Jordan.

World Health Organization (WHO) (2003).Chlorophenols in Drinking Water. Background Document for Development of WHO Guidelines for Drinking-Water Quality. 2nd ed. Vol. 2. WHO/WSH/03.04/47.

Zaccaroni, A.; Gamberoni, M.; Mandrioli, L.; Sirri, R.; Mordenti, O.; Scaravelli, D., Sarli, G. and Parmeggiani, A. (2009). Thyroid hormones as a potential early biomarker of exposure to 4-nonylphenol in adult male shubunkins (Carassius auratus). Science Total Environment,407(10): 3301-6.

Zaroogian, G.; Gardner, G.; Borsay Horowitz, D.; Gutjahr-Gobell, R.; Haebler, R. and Mills, L. (2001). Effect of 17-estradiol, o,p-DDT, octylphenol and p,p-DDE on gonadal development and liver and kidney pathology in juvenile male summer flounder (Paralichthysdentatus). Aquatic Toxicology, 54: 101-112.

Zeynep, D.B.; Süleyman, A. and Fikri, B. (2017). The physiological stress response to acute thermal exposure in Black Sea trout (Salmo trutta labrax Pallas, 1814), Turkish Journal of Veterinary and Animal Sciences, 41(3): 400-406.

Zilli, L.; Schiavone, R.; Zonno, V.; Storelli C. and Vilella S. (2004). Adenosine Triphosphate Concentration and b-D-Glucuronidase Activity as Indicators of Sea Bass Semen Quality, Biol.Reprod. 70: 1679-1684. 